\title{
Estilo e tipos de discurso na reportagem do gênero revista eletrônica
}

\author{
Style and Types of Discourse on a TV Report of the Genre \\ Electronic Magazine
}

\section{Estilo y tipos de discurso en el reportaje del género revista electrónica}

Livia Sprizão de Oliveira ${ }^{1}$

\begin{abstract}
RESUMO: A escolha de um gênero está entre as etapas iniciais do processo de criação textual e está intimamente ligada ao desenvolvimento do estilo individual do autor. Enunciados trazem cargas maiores ou menores de expressividade e entonação de acordo com o gênero adotado, uma vez que alguns são mais propícios do que outros ao estilo individual. Neste artigo iremos analisar trechos de uma reportagem de televisão, do gênero Revista Eletrônica, a fim de identificar recursos de linguagem que revelem as intenções do agir comunicacional e seus efeitos expressivos. Empregaremos duas bases teóricas distintas a fim de comparar seus aspectos dissonantes e complementares, observando aspectos estilísticos conforme esquema comunicacional de Jakobson (1969) e também a classificação segundo os tipos de discurso do quadro criado por Bronckart (2003). Seguiremos o conceito de gênero definido pelo interacionismo sócio-discursivo. Utilizaremos metodologia empírico indutiva, observando as particularidades do texto para verificar possíveis padrões. Pretendemos relacionar características predominantes e secundárias verificando seu alinhamento com as premissas do gênero e dos traços de estilo individual. Apontaremos para a multiplicidade de funções e intenções do enunciado que se sobrepõem de maneira hierárquica, mas, dificilmente, se encaixam por completo em fórmulas engessadas.
\end{abstract}

PALAVRAS ChAVE: Gênero. Estilo. Reportagem. Interacionismo sócio-discursivo.

ABSTRACT: The choice of a genre is among the initial stages of the textual creation process and is closely connected to the development of the author's individual style. Utterances may show different levels of expressiveness and distinct intonations according to the choice of the genre, since some are more inclined than others to the individual style. In this article we will analyze excerpts from a television report of the genre Electronic Magazine, in order to identify language resources that reveal the

\footnotetext{
1 Jornalista, doutoranda em Estudos da Linguagem (UEL). Contato: liviaoliveiratv@gmail.com
} 
intentions of the communication act and its effects on expressivity. We will employ two distinct theoretical bases in order to compare their dissonant and complementary aspects, by observing stylistic aspects according to Jakobson's communication scheme (1969) and also the classification according to the types of discourse in the framework brought by Bronckart (2003). We will follow the concept of genre defined by sociodiscursive interactionism. An inductive empirical methodology will be used, observing the particularities of the text to find possible patterns. We intend to relate predominant and secondary characteristics, verifying their alignment with the premises of the genre and the individual style traits. We will point out to the multiplicity of functions and intentions of the utterance that overlap themselves in a hierarchical way, but hardly fit entirely plastered formulas.

KEYWORDS: Genre. Style. Report. Social-Discursive Interactionism.

RESUMEN: La elección de un género está entre las etapas iniciales del proceso de creación textual y está íntimamente conectada al desarrollo del estilo individual del autor. Algunos enunciados traen cargas mayores o menores de expresividad y entonación de acuerdo con el género adoptado, ya que algunos son más propicios que otros al estilo individual. En este artículo analizaremos fragmentos de un reportaje de televisión, del género Revista Electrónica, a fin de identificar recursos de lenguaje que revelen las intenciones del actuar comunicacional y sus efectos expresivos. Emplearemos dos bases teóricas distintas con el objetivo de comparar sus aspectos disonantes y complementarios, observando aspectos estilísticos conforme esquema comunicacional de Jakobson (1969) y también la clasificación según los tipos de discurso del cuadro creado por Bronckart (2003). Seguiremos el concepto de género definido por el interaccionismo sociodiscursivo. Utilizaremos la metodología empírica inductiva, observando las particularidades del texto para verificar posibles patrones. Pretendemos relacionar características predominantes y secundarias verificando su alineamiento con las premisas del género y de los rasgos de estilo individual. Señalaremos la multiplicidad de funciones e intenciones del enunciado que se sobreponen de manera jerárquica, pero, difícilmente, se encajan por completo en fórmulas poco flexibles.

PALABRAS CLAVE: Género. Estilo. Reportaje. Interaccionismo sociodiscursivo.

\section{Introdução}

Durante a construção do texto, cada ação de linguagem determina resultados estéticos. Ainda que as decisões sejam limitadas por inúmeras variantes, inclusive as determinadas pelo gênero textual, a própria combinação entre escolhas pode conduzir a resultados únicos. Assim, podemos dizer que 0 conceito de originalidade está associado à seleção dos recursos linguísticos durante o processo construtivo, no campo da prática da linguagem. 
Neste trabalho trataremos especificamente da criação de textos escritos para serem falados na televisão, ideias que tomaram forma por meio da linguagem audiovisual para o gênero Revista Eletrônica. Vamos analisar um texto escrito pela repórter Sônia Bridi (2010) para uma reportagem exibida no programa dominical Fantástico, da Rede Globo.

Pretendemos explorar os recursos de linguagem que compõem o enunciado tanto no espectro da estilística textual quanto no espectro dos tipos discursivos, identificando e relacionando elementos textuais que evocam expressividade em diferentes modalidades. A partir desta análise será possível relacionar características predominantes e secundárias verificando seu alinhamento com as premissas do gênero e dos traços de estilo individual.

Para chegar à análise estabeleceremos as principais características da reportagem televisual, classificada como formato do gênero Revista Eletrônica; conceituaremos um modelo de análise estilística assim como dos tipos de discurso; relacionaremos as características textuais com as definições estilísticas e discursivas assumidas. Levaremos em consideração o esquema comunicacional proposto por Jakobson (1969) e acrescentaremos conceitos elaborados por Bronckart (2003) para quem "os gêneros são meios sociohistoricamente construídos para realizar os objetivos de uma ação de linguagem".

Podemos situar a escolha da linguagem e do gênero entre as etapas iniciais de um processo de criação. Da perspectiva do interacionismo sóciodiscursivo (ISD), nos servimos de um reservatório de gêneros e os utilizamos de acordo com a situação social. Esta ação social, que se dá por meio de atos de linguagem, se traduz em texto. Segundo Nascimento e Cristovão (2006) "a produção de um texto possui objetivos infinitos e é influenciada pela identidade do agente produtor desse texto."

A identidade do agente produtor e suas decisões no nível da textualização definem um estilo individual ou específico. Temos, portanto, uma esfera sociológica - que implica a contextualização e, portanto, os discursos que se constroem socialmente - e uma esfera psicolinguística, onde se dá a 
textualização, ou seja, onde se constituem as estratégias linguísticas (NASCIMENTO; CRISTOVÃO, 2006).

Enunciados tem estilo, expressividade e entonação, ou seja, posição valorativa. Identificar estilos individuais requer conhecimento sobre a natureza do enunciado e dos tipos de discurso envolvidos, além da contraposição entre o "eu" e o "outro". No mundo social, ou subjetivo, cada indivíduo constrói ações comunicativas intencionais. Os mecanismos de textualização e os mecanismos enunciativos de cada texto produzirão efeitos de coerência no interlocutor.

Partiremos das particularidades dos processos de constituição do texto para possíveis modelos de produção textual, assumindo que o ponto de partida da análise será a observação verificável.

\section{Gêneros na televisão}

Para Gomes (2011), gênero televisivo é uma estratégia de comunicabilidade que permite compreender as regularidades e as especificidades históricas dos produtos de televisão. A pesquisadora define os gêneros como "formas reconhecidas socialmente a partir das quais se classifica um produto midiático" (GOMES, 2011, p. 28)

Considerando que a programação da TV aberta brasileira possa ser dividida em categorias como Informação, Entretenimento, Propaganda e Educação (ARONCHI, 2013), podemos dizer que cada uma destas categorias pode ser subdividida em gêneros, tais como Esportivo, Humorístico, Documentário, Debate ou Telejornal, entre outros.

A vida impulsiona um movimento de criação e recriação constantes, portanto, novos gêneros podem surgir de necessidades relacionadas ao momento histórico ou das adaptações ao uso da linguagem. Entretanto, é comum que nos sirvamos de um "reservatório" de modelos socialmente compartilhados para efetivar a comunicação. Para Bronckart (2003, p. 101) essa é uma decisão estratégica: "o gênero adotado deverá ser eficaz em relação ao objetivo visado". 
Alguns gêneros televisivos transitam entre as categorias Informação e Entretenimento, compondo uma categoria mista, chamada de Infotenimento. 0 gênero Revista Eletrônica pode ser assim classificado por conter uma variação grande de formatos, que também trataremos aqui como enunciados. De acordo com Gomes (2012), o conceito de gênero televisivo

Deve possibilitar ao analista o reconhecimento da existência de relações sociais e históricas entre determinadas formas culturais - no nosso caso, os programas jornalísticos televisivos - e as sociedades e períodos nos quais essas formas são praticadas. (GOMES, 2012, p. 45).

A reportagem é um tipo de formato/enunciado presente em gêneros de diversas categorias na televisão. Até mesmo os programas de auditório costumam trazer alguma reportagem especial. Segundo Aronchi (2004), a reportagem tem como característica principal deixar o repórter em evidência, "narrando um assunto e fazendo entrevistas" (ARONCHI, 2004, p. 174).

Para Rezende (2000), a reportagem fornece um relato ampliado de um acontecimento, mostrando suas causas, correlações e repercussões. Neste trabalho vamos tratar da reportagem enquanto um dos enunciados do gênero Revista Eletrônica, situado na categoria Infotenimento. As reportagens televisivas são compostas por alguns elementos essenciais que, via de regra, orientam seu formato:

1) cabeça - uma introdução que apela ao conteúdo da reportagem;

2) off - texto escrito para ser falado pelo repórter;

3) texto imagético - sobrepõe-se ao off compondo a narrativa audiovisual;

4) passagem - repórter aparece no vídeo enquanto fala e torna-se parte da composição imagética,

5) sonoras - entrevistas gravadas com as fontes.

A ordem desses elementos pode variar sem prejuízo para a estrutura do texto, bem como outros elementos secundários podem ser adicionados (trilha 
sonora, legendas e gráficos) para causar efeitos expressivos, facilitar a compreensão ou servir como recursos argumentativos. Neste trabalho concentraremos nossa atenção no elemento chamado de off, ou seja, no texto escrito para ser falado pela repórter, aparte das imagens.

\section{Gênero e estilo}

O estilo está intimamente ligado aos gêneros textuais e aos tipos de discurso. As balizas definidas socialmente para definir o modelo do gênero são referência para o desenvolvimento do estilo individual dentro de um conjunto de recursos reconhecidos coletivamente. A ação individual do autor insere-se nos conhecimentos e atividades coletivas.

Dentro de um mesmo gênero reconhecível socialmente, cada autor faz suas próprias escolhas, lexicais, fraseológicas e gramaticais. Entendemos que 0 estilo textual depende das seleções ao manipular a língua. Cada indivíduo é único e, ao atuar em contextos específicos, de acordo com sua própria identidade, tem condições para fazer escolhas únicas.

No século XX, a Estilística era uma disciplina relacionada à linguística para estudar os aspectos afetivos da língua. Charles Bally, discípulo de Ferdinand de Saussure, foi um dos precursores das pesquisas sobre os fenômenos de sensibilidade que se manifestam no uso da língua e que estão além do que a gramática normativa consegue definir, identificando conceitos subjetivos na fala e na escrita que expressam sentimentos e evocam ideias.

Conforme Martins (2008), Bally "não se volta para o discurso ('parole'), o uso individual da língua, mas para o sistema expressivo da língua coletiva ('langue')", iniciando assim uma Estilística da língua ou da expressão linguística, desconsiderando estilos individuais e considerando o todo que influencia o ser humano a revelar sentimentos ou estados psíquicos por meio da sistematização dos recursos que a língua oferece. 
Partindo do conceito de estilo individual, Leo Sptizer introduziu outra abordagem para a Estilística, que pode ser chamada de literária ou genética, e que concentra atenções no estilo do autor, suas vivências e intenções para criar a obra. Para Brito e Panichi (2013, p. 112), este enfoque "abre-se em dois prismas: o estudo da língua, dos hábitos linguísticos do indivíduo nas construções consideradas abstratamente, portanto, fora do texto; e o estudo da palavra, das expressões contextualizadas".

Roman Jakobson (1969) trouxe para a Estilística um viés estruturalista ligando a análise da mensagem à análise do sistema. A criação textual estaria relacionada, basicamente, com duas ações: seleção e combinação. Partindo do entendimento que a mensagem tem objetivos a cumprir, ele traçou um esquema comunicacional composto por seis funções que relacionam a gramática e a estrutura da linguagem com os objetivos que elas cumprem.

O interacionismo social bakthiniano critica a estilística estrutural, assumindo que a língua está inserida nas práticas sociais e, portanto, nas práticas discursivas. Dentro dessa lógica, os enunciados concretos produzem elos que resgatam discursos e desencadeiam outros. Consideramos, então, que a escolha do gênero influencia no desenvolvimento do estilo, uma vez que alguns gêneros textuais permitem explorar um número maior de recursos expressivos do que outros.

\footnotetext{
O enunciado é individual e, por isso, pode refletir a individualidade de quem fala (ou escreve). Em outras palavras, possui um estilo individual. Mas nem todos os gêneros são aptos para refletir a individualidade da língua, ou seja, nem todos são aptos ao estilo individual. (BAKHTIN, 1997, p. 283)
}

O enunciado concreto pressupõe expressividade, estilo e posicionamento, ou seja, valoração. Para Bakhtin, o enunciado será constituído na forma do gênero e o estilo ligado às formas típicas do enunciado e dos tipos de discurso. Nascimento e Gonçalves (2018) propõem que a análise do enunciado considere: 1) o contexto sociointeracional; 2) a análise do texto propriamente dito; 3) a 
detecção das funções sintático/semânticas que explicitam as intenções do agir comunicacional.

Sendo assim, a expressividade pode ser alvo da análise estilística por meio da observação do uso da língua e seus recursos gramaticais, semânticos e lexicais. No entanto, "um estilo não se detecta na simples comparação de um texto frente a uma regra ou a um dispositivo qualquer; é preciso haver um relacionamento intertextual." (BRITO; PANICHI, 2013, p. 123).

É certo que o período histórico, as experiências pessoais do autor e o público a quem se dirige o texto são alguns dos fatores que podem interferir nos efeitos de sentido que se deseja provocar. "O estilo, entretanto, a sua maneira de atuar sobre tais coisas, está dentro do homem, é ele próprio. E assim, vão esses sujeitos desenvolvendo sua maneira própria de escrever, dentro de um gênero, dentro de uma época" (BRITO; PANICHI, 2013, p. 113).

Gêneros textuais de caráter predominantemente denotativos tendem a limitar o estilo individual, enquanto aqueles em que predominam características subjetivas tendem a ser mais receptivos os recursos linguísticos que valorizam a expressividade. Ainda conforme Bakhtin (1997, p. 283), "os gêneros mais propícios ao estilo individual são os literários. Os menos propícios são aqueles que requerem formas padronizadas, como documentos oficiais e as notas de serviços".

Do ponto de vista do jornalismo de televisão, podemos dizer que os gêneros da categoria informação são menos propícios ao estilo individual, em especial as notícias classificadas como hard news. Por tratarem de política, economia e serviços, esses enunciados tendem a ser mais "enxutos" e menos adjetivados, justamente para tentar reduzir julgamentos de valores e interpretações dúbias. Já nas categorias Entretenimento e Infotenimento há mais flexibilidade para lidar com a linguagem, e mais enunciados com características de soft news.

No gênero Revista Eletrônica, há uma grande variedade de enunciados/formatos, mas as reportagens costumam ter lugar de destaque, 
firmando uma espécie de compromisso com a apresentação completa de conteúdos de caráter jornalístico. Por outro lado, o entretenimento e, consequentemente, a subjetividade tem espaço garantido. O Fantástico tem o slogan "show da vida", deixando clara a intenção promover um espetáculo de informações, sons e imagens.

O programa busca apresentar, conforme o sítio institucional do programa, "jornalismo, prestação de serviços, humor, dramaturgia, documentários exclusivos, música, reportagens investigativas, denúncias, ciência, além de espaço para a experimentação de novas linguagens e formatos" (GLOBO, 2015). Por se tratar de um programa semanal, as reportagens são mais longas do que as de um telejornal diário, são produzidas com mais recursos técnicos e humanos, e recebem uma produção especial.

O endereçamento, ou seja, o modo como um gênero busca se relacionar com seu público, também pode interferir nas escolhas estilísticas. Conforme Bakhtin (1997, p. 324) "o estilo depende do modo que o locutor percebe e compreende seu destinatário, e do modo como ele presume uma compreensão responsiva ativa". Pretendemos explorar as questões de estilo neste trabalho fazendo uma correlação entre aspectos textuais e discursivos, levando em consideração o processo criativo da repórter autora.

\section{A reportagem e a estilística textual}

Consideraremos neste trabalho a chamada Estilística Funcional, baseada no esquema comunicacional de Roman Jakobson. De acordo com Rei e Simões (2014), este sistema funciona como um "ponto de interseção entre a língua e a literatura, e entre todas as estilísticas". Jakobson (1969), definiu seis funções da linguagem, cada uma com ênfase em um fator da comunicação: a função referencial, com ênfase no referente; a função emotiva, com ênfase no emissor; a função conativa, com ênfase no receptor; a função fática, com ênfase no canal; 
a função poética, com ênfase na mensagem; e a função metalinguística, com ênfase no código.

Cada uma dessas funções se concentra em um dos elementos necessários para a comunicação - emissor, receptor, canal, código, mensagem e contexto e cada um desses elementos exigiria um tipo de análise - exceto a função fática, que é voltada para o canal. A Estilística Funcional englobaria todas elas, observando tanto os efeitos expressivos do texto, quanto a organização dos signos.

Quadro 1 - Estilísticas e efeitos expressivos

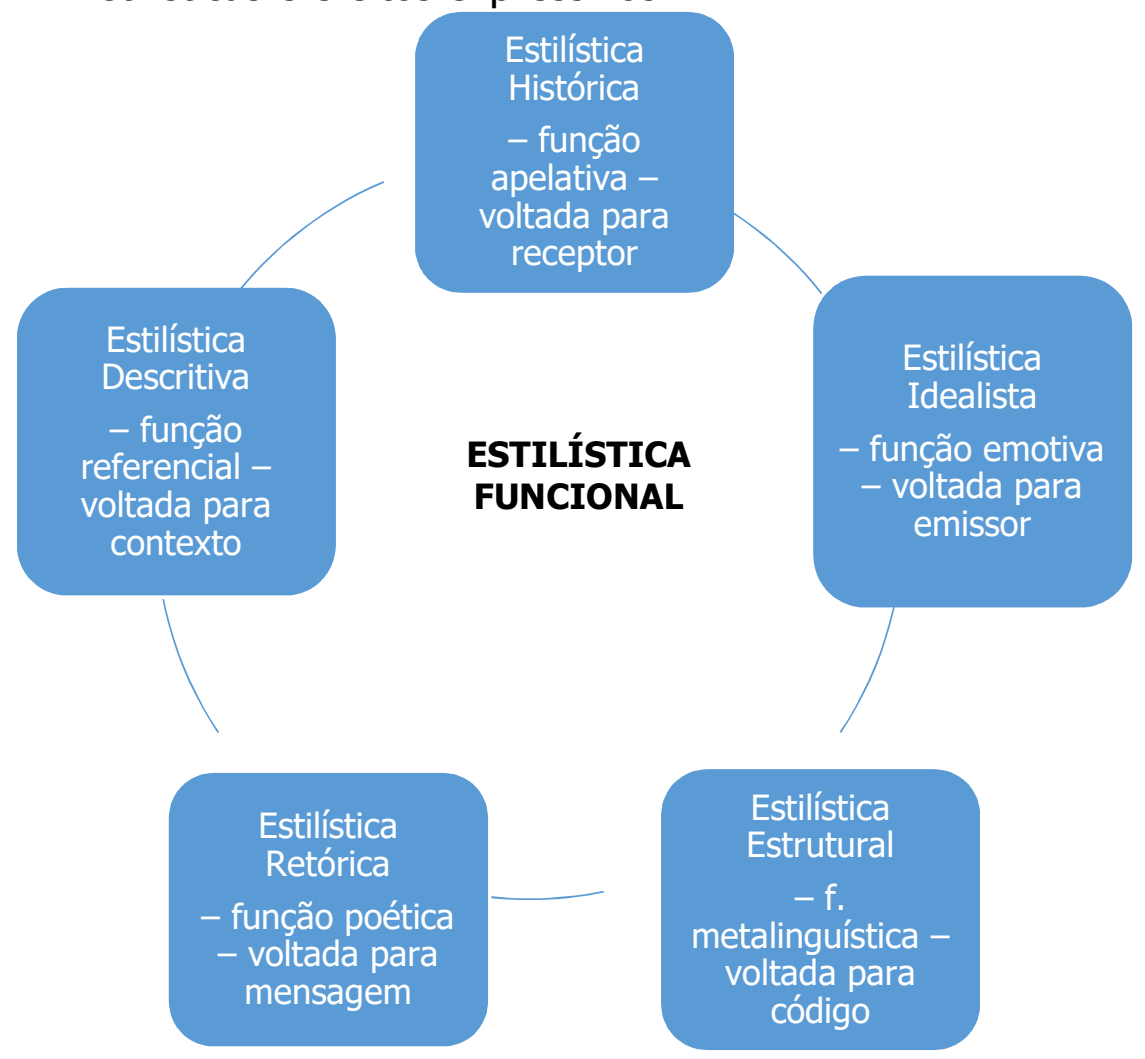

Fonte: elaborado pela autora (2016).

Tomando como base estes princípios, podemos situar o texto jornalístico no campo da estilística descritiva, com ênfase na função referencial, uma vez que a mensagem se dirige ao contexto, portanto a função de linguagem predominante é a função referencial, ou de representação, "elaborada em função de uma certa repetibilidade das normas do código, produzindo informações definidas, claras, transparentes, sem ambiguidades" (CHALHUB, 2006, p. 10), 
sendo um recurso usado para causar um efeito de distanciamento maior entre 0 autor e o fato narrado.

Brito e Panichi (2013), classificam a função referencial como denotativa, voltada para a informação com o objetivo de transmitir dados com objetividade. "Nesta função prevalece o texto escrito em terceira pessoa, tais como os textos jornalísticos, científicos, jurídicos, centrando-se no referente, naquilo de que se fala" (BRITO; PANICHI 2013, p. 118).

A estilística descritiva é predominante no texto jornalístico, mas um enunciado pode ter várias funções de linguagem secundárias, que impactam diretamente no estilo individual do autor. Embora a função referencial reporte à objetividade, elementos subjetivos podem se manifestar na seleção lexical, na entoação da voz, nas expressões faciais e nas representações imagéticas. Na reportagem de televisão, esta subjetividade também pode ser percebida pelo posicionamento da câmera e pela expressividade provocada pelos movimentos do cinegrafista, que não exploraremos aqui.

No entanto, o esquema proposto por Jakobson desconsidera o contexto de produção textual, ou seja, o lugar físico e o momento histórico em que um texto é produzido. Estas questões também interferem nos efeitos expressivos e estão mais ligadas ao discurso do que ao texto. Determinados atos de linguagem podem assumir contornos expressivos diferentes dependendo do contexto.

Para Bronckart (2003), as funções da linguagem, demonstradas anteriormente, são muito genéricas. "Para identifica-las é preciso conhecer os objetivos da ação de linguagem à qual o texto está articulado. Os objetivos de um texto serão teoricamente infinitos" (BRONCKHART, 2003, p 96-97). O pesquisador sociointeracionista propõe uma outra classificação, decompondo a arquitetura do texto em quatro níveis:
1) gêneros textuais
2) tipos de discurso (teórico, interativo relato e narração)
3) textualização (coerência) 
4) responsabilidade enunciativa (vozes postas em cena na textualidade)

\section{A reportagem e os tipos de discurso}

Nos textos jornalísticos a busca da objetividade é uma espécie de mantra propagado por editores e manuais de redação. Tal efeito de imparcialidade é forjado no uso da terceira pessoa, da ordem direta e na supressão de adjetivos, por exemplo. Evitam-se figuras de linguagem, palavras de duplo sentido e 0 emprego aleatório de sinônimos. Recomenda-se que as fontes entrevistadas sejam classificadas antes pela profissão, depois pelo nome, como estratégia para expressar formalidade e impessoalidade.

Na década de 1990, o manual de redação do jornal Estado de São Paulo recomendava que jornalistas jamais deixassem informações subentendidas e orientava que repórteres jamais expressassem opiniões, deixando comentários para os editoriais e colunas assinadas. Ainda hoje é assim, neste e em outros jornais de grande circulação.

\footnotetext{
Faça textos imparciais e objetivos. Não exponha opiniões, mas fatos, para que o leitor tire deles as próprias conclusões. Em nenhuma hipótese se admitem frases como: Demonstrando mais uma vez seu caráter volúvel, o deputado Antônio de Almeida mudou novamente de partido. Seja direto: $O$ deputado Antônio de Almeida deixou ontem o PMT e entrou para o PXN. É a terceira vez em um ano que muda de partido. O caráter volúvel do deputado ficará claro pela simples menção do que ocorreu. (MARTINS FILHO, 1997, p. 17).
}

Ao delimitar o espaço de tempo e o número de vezes que o deputado mudou de partido, aciona-se o conhecimento socialmente compartilhado, ou a memória coletiva, buscando-se o entendimento sobre o "caráter volúvel" do parlamentar. Sendo assim, seria possível evitar opiniões e subentendidos? Ou o simples encadeamento de frases, a escolha das informações e a forma como são dispostas revelam intenção?

Assumiremos então que gênero, estilo e discursividade estão intimamente ligados e encadeados, uma vez que são resultados das escolhas do autor durante 
o processo de criação. O gênero Revista Eletrônica, escolhido para o corpus deste trabalho, permite uma atuação mais personalizada dos jornalistas durante a produção dos enunciados, uma vez que entre os objetivos estão: emocionar, criar empatia e garantir um show, além de oferecer informação. No formato Reportagem, perceberemos, observando o texto analisado, que a repórter expressa sensações e tem liberdade para imprimir estilo próprio, assumido no uso da primeira pessoa.

O processo de criação de Sônia Bridi reflete-se em seu estilo individual. "Meu método é viver e testemunhar intensamente o momento, deixar gravar na memória. Ao rever as imagens gravadas, essa memória volta fácil", revela Bridi². Depois de anotar as impressões emocionais ela relê a pesquisa, sedimenta ideias e a partir daí o texto toma forma rapidamente.

Na televisão, o texto do repórter é reforçado pelo texto imagético e, muitas vezes, pela trilha sonora. As reportagens de uma Revista Eletrônica podem ganhar ainda outros elementos, tais como gráficos, vinhetas e efeitos especiais. Quanto maiores as possibilidades de explorar recursos de linguagem, maior pode ser a carga expressiva de um enunciado, ou seja, sua discursividade.

Os tipos de discurso são classificados por Bronckart (2003, p. 145) como "formas linguísticas que são identificáveis nos textos e que traduzem a criação de mundos discursivos específicos, sendo esses tipos articulados entre si por mecanismos de textualização e mecanismos enunciativos". O pesquisador criou um quadro de dupla entrada para demonstrar como os arquétipos psicológicos, ou seja, os aspectos abstratos da língua, que se apresentam dando origem a quatro mundos discursivos com características diferentes.

Os mundos classificados no eixo do Narrar estão situados em outro tempo ou espaço, estão em disjunção com o mundo ordinário, podendo ter tendências históricas ou ficcionais. Já os mundos do eixo do Expor estão atrelados ao mundo ordinário dos envolvidos no ato de linguagem, ou seja, em conjunção.

\footnotetext{
2 Em entrevista à autora.
} 
Quando passamos para dos eixos da implicação e autonomia, verificamos que alguns textos apresentam referências dêiticas e pedem um conhecimento mínimo do contexto de produção. Estes são os chamados textos implicados, integrados ao conteúdo temático. Já os textos considerados autônomos, dispensam conhecimento das ações de produção para sua interpretação.

Quadro 2 - Tipos de discurso

\begin{tabular}{|c|c|c|c|}
\hline & & CONJUNÇÃO & DISJUNÇÃO \\
\hline & & EXPOR & NARRAR \\
\hline ATO DE PRODUÇÃO & IMPLICAÇÃO & Discurso interativo & $\underline{\text { Relato interativo }}$ \\
\hline ATO DE PRODUÇÃO & AUTONOMIA & Discurso teórico & Narração \\
\hline
\end{tabular}

Fonte: Bronckart (2003, p. 157).

Veremos que no formato/enunciado Reportagem predominam características do relato interativo, uma vez que esta modalidade de discurso exige conhecimento do contexto de produção, ou seja, está no eixo horizontal implicado, e ao mesmo tempo no eixo vertical do universo do Narrar histórico, porque que conta um fato considerado real, mas que aconteceu em outro tempo e em outro lugar, disjunto do ato de linguagem.

As principais características do Relato Interativo são:

- Mundo discursivo cujas coordenadas gerais são disjuntas das coordenadas do mundo ordinário do agente-produtor e dos agentes ouvintes

- Mundo discursivo situável em referência aos agentes

- Narrar que implica personagens e acontecimentos

- Implicação dos parâmetros físicos da ação de linguagem em curso 
No entanto, perceberemos que outras modalidades de discurso também podem permear o relato interativo ao longo da reportagem.

\section{Análise de corpus}

Analisaremos fragmentos da reportagem sobre o derretimento das calotas polares, da repórter Sônia Bridi (2010), para o quadro Terra, que tempo é esse? do programa dominical Fantástico, da Rede Globo, do gênero Revista Eletrônica. Do ponto de vista da Estilística Funcional, percebemos que o texto é predominantemente descritivo. No entanto, o uso de farta adjetivação (imensa, imponente), metáforas (mar de icebergs) e hipérboles (um pequeno tsunami) fazem emergir a retórica, que utiliza funções de linguagem voltadas para a mensagem e para a argumentação.

Quando Sônia Bridi (2010) mistura expressões subjetivas como "um gigante que se desmancha" com outras objetivas como "100 metros para fora d'água", opta por um estilo que compartilha informações e, ao mesmo tempo, emoções. Neste sentido, as escolhas textuais do enunciado estão alinhadas com a proposta do gênero Revista Eletrônica, ao qual pertence.

Do ponto de vista discursivo, a reportagem é um relato interativo, porém, os limites são bastante permeáveis e admitem a presença de discursos característicos de outros quadrantes. Segundo Bronckart (2013, p. 175)

[...] o relato interativo é um tipo de discurso, em princípio monologado, que se desenvolve em uma situação de interação que pode ser real (e originalmente oral) ou posta em cena, no quadro de um gênero escrito como o romance ou a peça de teatro. Esse caráter monologado se traduz principalmente pela ausência de frases não declarativas.

No entanto, as frases não declarativas (que no nível textual poderiam caracterizar a função apelativa, voltada para o receptor), fazem parte da linguagem audiovisual de televisão, em especial nos gêneros que pretendem simular um diálogo com o telespectador, como é o caso do gênero Revista 
Eletrônica. Estamos tratando aqui de um enunciado que busca responder à pergunta "que tempo é esse?". Percebemos assim a permeabilidade dos limites entre diferentes tipos de discurso.

Vejamos a transcrição de alguns trechos da reportagem de Sônia Bridi (2010):

(imagens acompanhadas de música instrumenta) Avançamos por um mar de icebergs, até subir o fiorde, um canal profundo que avança para dentro da ilha...Quanto mais nos aproximamos da geleira, mais gelo na água...

(barulho bloco batendo no barco) Os blocos batem no barco, mas não ameaçam nossa segurança...

As encostas de pedra descobertas contrastam com o branco da água (trilha se torna mais suave)

E lá está ela, a geleira de Eki, imensa, imponente. Um paredão congelado se erguendo a 100 metros pra fora da água. Um gigante que se desmancha diante dos nossos olhos. (imagens e barulho gelo da geleira caindo na água) Terra, que tempo é esse? (vinheta reportagem) Estamos na Groenlândia. (arte gráfica ilustrativa) $400 \mathrm{~km}$ ao norte do círculo polar ártico. A maior ilha do mundo - uma área maior que dos estados Amazonas, Acre, Roraima e Rondônia, juntos - é coberta por um manto de gelo de até $3 \mathrm{~km}$ e meio de espessura.

Esta é a região do planeta onde as consequências do aquecimento global são mais visíveis... e mais perigosas. $O$ derretimento da calota polar não tem grande impacto no nível dos oceanos, porque é mar congelado que derrete. Mas o gelo da Groenlândia está sobre a Terra. Se tudo derretesse, os oceanos subiriam 7 metros. Sete metros, só com o degelo da Groenlândia. (imagens com som ambiente degelo) [...]

(Passagem): As geleiras parecem estáticas, mas, na verdade, elas são como rios de gelo que correm bem devagar. Durante mais de cem anos o cientista tem acompanhado a velocidade desse deslocamento aqui na Groenlândia. E elas mantiveram, até 1996, o mesmo ritmo. (recomeça trilha de suspense) Até que começaram a ganhar velocidade. $\mathrm{E}$ em menos de 15 anos já estão correndo 4 vezes mais rápido. [...]

O físico Jay Swally, da Nasa, estuda o gelo da Groenlândia há 30 anos. (corta trilha, deixando apenas a voz do cientista) Ele mostra no mapa, feito com sensores de altitude do satélite, como, na costa, o gelo já ficou de 10 a 20 metros mais fino, em apenas dez anos. (volta trilha) Mas é nas bordas que o maior desastre acontece. 0 gelo derrete mais, e as geleiras aceleram. $O$ volume de gelo jogado no mar, no ano passado foi de $200 \mathrm{~km} 3$. (gráficos reforçam). Pare para imaginar esse volume! Duzentos cubos de gelo com $1 \mathrm{~km}$ de altura, um de largura, um de profundidade. Entrevista com Jay Swally (sem trilha).

Percebemos que se trata de um relato interativo pelo caráter monologado do texto, pelo uso da primeira pessoa do plural, do tempo pretérito e por uma densidade verbal alta. Esses recursos, que se referem diretamente ao agente 
produtor do texto, revelam a implicação dos parâmetros da interação verbal. Temos ainda o uso de argumento por autoridade, com informações creditadas a pesquisadores especializados, que situam o relato no polo de um narrar realista, ou seja, veicula um conteúdo válido no mundo ordinário (não ficcional).

Além disso, o uso de dêiticos espaciais e temporais (ex.: Groelândia, círculo polar ártico, esta região do planeta, 1996, em menos de quinze anos) também indica a disjunção entre o ato de linguagem e mundo ordinário, ou seja, o momento compartilhado entre agente emissor e agente receptor, situando geograficamente e historicamente os agentes.

Contudo, no momento em que a repórter entrevista o pesquisador, entra em cena um outro tipo de discurso, caracterizado pelo diálogo e pelo comentário sobre o mundo ordinário, o discurso interativo. Nesse caso, cruzam-se os eixos do expor implicado em conjunção com o mundo dos agentes do ato de linguagem que, dentro do enunciado, são o repórter e o entrevistado. Para incluir o telespectador no processo, poderíamos chamar esse tipo discursivo de discurso interativo relatado.

Percebemos também a presença do discurso teórico quando a repórter Sônia Bridi (2010) utiliza conhecimentos enciclopédicos como recurso de argumentação:

(trilha sonora ao fundo) O gelo reflete parte da radiação solar para o espaço. Quando o gelo derrete, a água do mar, ou as pedras descobertas, absorvem calor. Com o gelo derretendo no verão, então $98 \%$ da radiação é absorvida pelo mar, em vez de voltar para o espaço. $\mathrm{E}$ isso aquece a água. (imagens reforçadas por gráficos simulando a radiação).

Neste caso, temos um texto autônomo, ou seja, que não faz referência aos agentes do ato de linguagem, monologado e que faz uso do presente genérico, traduzindo por meio desse tempo verbal a conjunção com o mundo ordinário. Encontramos também conectores de caráter lógico-argumentativo indicando relação entre causa e consequência (Ex.: quando o gelo derrete... então, 98\% da radiação é absorvida pelo mar). 


\section{Considerações Finais}

Partindo da observação da reportagem de Sônia Bridi verificamos que o gênero Revista Eletrônica, na categoria Infotenimento, é receptivo ao exercício do estilo individual, permitindo que a autora utilize recursos expressivos, incluindo adjetivação e figuras de linguagem para transmitir informação e ao mesmo tempo emoção. A trilha sonora e a narração da repórter ajudam a conduzir as intenções.

Dessa forma, confirmamos um princípio proposto por Bakhtin sobre os limites convencionados socialmente para caracterizar um gênero. Embora tais limites não sejam rígidos ou absolutos, são modelos utilizados pelos autores para atingir objetivos comunicacionais. No caso do programa Fantástico, o endereçamento, ou seja, a percepção do agente receptor, pede enunciados que cumpram o papel de informar e entreter simultaneamente, quebrando a objetividade propagada nos manuais do jornalismo convencional que tão bem serve às chamadas hard news.

Os enunciados de um gênero podem ser analisados na superfície do texto, por meio da verificação dos recursos estilísticos adotados, e também em um segundo nível, que considera o contexto de produção e alcança os efeitos expressivos por meio da identificação dos tipos de discurso. Optamos por fazer uma combinação entre análise textual estilística - derivada do esquema comunicacional de Jakobson - e a classificação segundo os tipos de discurso proposta por Bronckart.

Nenhuma das propostas alcança a complexa multiplicidade de intenções dos atos de linguagem que compõe o texto. Embora predomine na reportagem de televisão a função de linguagem referencial, no nível textual, e o relato interativo, no nível discursivo, existem outras funções e tipos de discurso que dão sustentação à arquitetura textual, embora estejam em segundo, ou terceiro plano. 
A sobreposição de funções de linguagem e tipos de discurso se dá em diversos gêneros textuais. No caso da reportagem jornalística para televisão, o processo de mesclagem se dá pela necessidade de aproximar o texto escrito da língua falada, e pela própria característica híbrida do gênero Revista que tem a combinação entre informação de credibilidade e entretenimento como base.

\section{Referências}

ARONCHI, José Carlos. Gêneros e formatos na televisão brasileira. São Paulo: Summus, 2004.

ARONCHI, José Carlos. Roda dos gêneros da televisão digital interativa ferramenta para o desenvolvimento de novos gêneros e formatos de conteúdo para multiplataformas digitais interativas. In: INTERCOM - SOCIEDADE BRASILEIRA DE ESTUDOS INTERDISCIPLINARES DA COMUNICAÇÃO, 18., 2013, Bauru. Anais [...]. Bauru, 2013. Disponível em: portalintercom.org.br/anais/sudeste2013/ resumos/R38-1719-1.pdf. Acesso em: 5 dez. 2016.

BAKHTIN, Mikhail Mjkhailovitch. Os gêneros do discurso. In: BAKHTIN, Mikhail Mjkhailovitch. Estética da criação verbal. Tradução de Maria Ermantina Galvão G. Pereira. 2. ed. São Paulo: Martins Fontes, 1997. p. 278-326.

BRIDI, Sônia. Terra, que Tempo é Esse? Fantástico, Rio de Janeiro, 17 out. 2010. Disponível em:

http://redeglobo.globo.com/videos/t/jornalismo/v/fantastico-estreia-da-serieterra-que-tempo-e-esse-2010/6293803/. Acesso em: 9 maio 2019.

BRITO, Diná Tereza de; PANICHI, Edina Regina Pugas. Crimes contra a dignidade sexual: a memória jurídica pela ótica da estilística léxica. Londrina: Eduel, 2013.

BRONCKART, Jean Paul. Atividade de linguagem, textos e discursos. por um sócio-interacionismo-discursivo. Tradução de Anna Rachel Machado, Péricles Cunha. São Paulo: EDUC, 2003.

CHALHUB, Samira. Funções da linguagem. 12. ed. São Paulo: Ática, 2006.

GLOBO. Fantástico: o Programa. 2015. Disponível em: https://globointernacional.globo.com/Asia/Paginas/fantastico.aspx. Acesso em: 9 maio 2019. 
GOMES, Itania Maria Mota. Estabilidade em fluxo: uma análise cultural do Jornal Nacional, da Rede Globo. In: GOMES, Itania Maria Mota Gomes (org.). Análise de telejornalismo: desafios teórico-metodológicos. Salvador: EDUFBA, 2012. p. 39-58.

GOMES, Itania Maria Mota. Metodologia de análise de telejornalismo. In: GOMES, Itania Maria Mota (org.). Gêneros televisivos e modos de endereçamento. Salvador: EDUFBA, 2011. p. 17-48.

JAKOBSON, Roman. Linguística e comunicação. Tradução de Izidoro Blikstein e José Paulo Paes. São Paulo: Cultrix, 1969.

MARTINS FILHO, Eduardo Lopes. Manual de redação e estilo de $O$ Estado de $S$. Paulo. 3. ed. São Paulo: O Estado de S. Paulo, 1997.

MARTINS, Nilce de Sant 'Anna. Introdução à estilística: a expressividade na língua portuguesa. São Paulo: EDUSP, 2008.

NASCIMENTO, Elvira Lopes; CRISTOVÃO, Vera Lúcia Lopes. Gêneros textuais e ensino: contribuições do interacionismo sócio-discursivo. In: KARWOSKI, Acir Mario; GAYDECZKA, Beatriz; BRITO, Karin S. Gêneros textuais. reflexões e ensino. Rio de Janeiro: Lucerna, 2006.

NASCIMENTO, Elvira Lopes; GONÇALVES, Adair Vieira. A perspectiva interacionista sociodiscursiva no trabalho educacional. In: CRISTOVÃO, Vera Lucia Lopes (org.). Gêneros (textuais / discursivos): ensino e educação (inicial e continuada) de professores de línguas. Campinas: Mercado de Letras, 2018.

REI, Cláudio Artur O.; SIMÕES, Darcilia. Língua e estilo: uma tessitura especial. In: OLIVEIRA, Esther G.; SILVA, Suzete (org.). Semântica e estilística: dimensões atuais do significado e do estilo. Homenagem a Nilce Sant' anna Martins. Campinas, SP: Pontes Editores, 2014. p. 445-461.

REZENDE, Guilherme Jorge de. Telejornalismo no Brasil, um perfil editorial. São Paulo: Summus, 2000. 